PRESENT: $\quad$ Councillor Adrian Walmsley (Chairman)

Councillors Myles Hogg (Deputy Chairman), Alex Black, Tom Blackmore, Pamela Booher, Lynn Clare, Razia Daniels, Graham Heatley, Brian Jones, Bob Rudd, Andrew Williams and Norman Wright

Apologies for absence were received from Councillors Malcolm Byram, John Leather and Elton Watson

Visiting Members: $\quad$ Councillor Samantha Dixon

Officers in attendance: Andy Challinor

Peter Willett

Guy Morris

Allison Jackson

Judith Bramhall

Stephanie Cornes
- Regulatory Services Manager (Compliance \& Commercial Support)

- Team Leader (Licensing Enforcement)

- Lead Officer Licensing Authority

- Lead Officer Licensing Enforcement and Compliance

- Senior Solicitor

- Democracy \& Elections Officer

\title{
DECLARATIONS OF INTERESTS
}

There were no declarations of interest.

\section{PUBLIC QUESTION TIME - OPEN SESSION}

The following addressed the Committee under Public Speaking Time:

1. Tommy Owens, UNITE Union

Mr Tommy Owens addressed the Committee and spoke against item 6 on the agenda. Mr Owens expressed concerns over the two passenger vehicle; the Mercedes 'Fortwo' on safety grounds and requested the Committee refuse the application.

\section{Mr Craig Jackson and Mr Gary Roberts, Applicants for Onesie Cars}

Mr Craig Jackson and Mr Gary Roberts addressed the Committee supporting their application detailed in item 6 on the agenda. They explained to Members that their venture to use Smart Fortwo vehicles for private hire use would increase customer choice, reduce vehicle emissions and provide customers with a more affordable service. 
the minutes of the meeting held on 18 June 2013 be agreed as a correct record.

\section{APPLICATION FOR RENEWAL OF A SEX ESTABLISHMENT LICENCE - PLATINUM LOUNGE, 42 BRIDGE STREET ROW, CHESTER CH1 1NN}

Members received a report requesting consideration for the renewal of a Sex Establishment Licence to Bridgerow Ltd for the Platinum Lounge, 42 Bridge Street Row, Chester, $\mathrm{CH} 1$ 1NN.

Members were reminded that the Council had adopted Section 2 and Schedule 3 of the Local Government (Miscellaneous Provisions) Act 1982 as amended by Section 27 of the Policing and Crime Act 2009 and the amendments came into effect on 9 May 2011. The Council now had a greater degree of control of Lap Dancing Clubs; now defined as Sexual Entertainment Venues. These new powers enable the Council to promote its Corporate Priority of Safer and Stronger Communities.

The application was submitted by Bridgerow Ltd on 3 May 2013. The premises were granted the original Sex Establishment (Sexual Entertainment Venues) Licence on 21 February 2012. That licence continued in place until such time as the current application was determined. Members were referred to the opening hours of the current premises licence issued under the Licensing Act 2003 which was attached at Appendix 2 to the report.

Members were advised that all relevant consultees were notified in accordance with paragraph 8 of the Statement of Licensing Policy Sex Establishments. Notice of the current application for the renewal of a Sex Establishment Licence was displayed on the premises and published in a newspaper circulating in the area and eight written objections had been received from a Ward Councillor, local businesses and from Chester residents. Those objections were attached to the report at Appendix 3. In summary, the main concerns were about the following;

- Suitability of location and its close proximity to residential properties and children visiting the Dewa Roman Experience.

- Concerns about the character of the locality where the premises was situated on Chester's historic rows.

- Fears that nuisance behaviour and crime and disorder will increase, namely crimes against women, trafficking and under-age performers.

- Inappropriate advertising and litter from leaflet distribution.

Concerns about sexual objectification of women; fears that a Sexual Entertainment Venue cheapens the reputation of Chester City had also been raised but were matters outside the remit of the legislation specifically applying to Sex Entertainments. The Licensing Section also received seven letters and a petition in support of the renewal application. The letters and petition were attached to the report at Appendix 4.

The Licensing Committee heard verbal evidence from the following persons:

1. Lisa Sharkey, Solicitor for the Applicant

2. Philip Archer- Jones, Director

3. Nigel Woodhouse, Director 
4. Councillor Samantha Dixon

5. Anthony Lyons, Solicitor for Vanessa Bond and Whitefriars Residents Association

6. Vanessa Bond

7. Deborah Lomas

8. James Kenny

9. Jolene Wells

10. Alan Hoey

Members noted that there had been no objections from Environmental Protection and Cheshire Police. Members were informed that the premises had received 13 unannounced compliance checks during the last year; details of these were attached to the report at Appendix 6.

\section{DECIDED: That}

the application for the renewal of a Sexual Entertainment Venue licence for Platinum Lounge, 42 Bridge Street Row, Chester, $\mathrm{CH} 11 \mathrm{NN}$, be refused.

\section{APPLICATION FOR CONSIDERATION OF AMENDMENT TO CHESHIRE WEST AND CHESTER BOROUGH COUNCIL'S PRIVATE HIRE VEHICLE LICENCE CONDITIONS}

Members were reminded that at the Licensing Committee meeting on 18 June 2013 an application was considered to amend the Cheshire West and Chester Private Hire Vehicle conditions to permit the licensing of single passenger "Fortwo" Smart Car. Members authorised officers to undertake a trade consultation on the proposal to licence a single passenger vehicle for private hire.

Members were now requested to consider the results of the consultation and determine whether to vary the licensing conditions to permit the licensing of single passenger private hire vehicles. Any variation to conditions would require amendments to the Private Hire Vehicle Licence Conditions as set out in the Cheshire West and Chester Council 'Private Hire Vehicle Conditions' and specifically condition 1.5 which related to the requirements for all private hire vehicles to have a minimum of four doors.

Members considered the application from Mr Gary Thomas Roberts and Mr Craig Daniel Jackson, who were in attendance, to operate a two door vehicle, namely a Mercedes 'Smart Fortwo'. Following the meeting, Officers started a four week consultation with the trade which ended on 16 August 2013. The Council received fifteen responses; 11 were against the proposal and four were in favour of amending the conditions.

A discussion ensued and some Members felt that by amending condition 1.5 to allow the single passenger "Fortwo" Smart Car, would offer more choice for the customer as well as being environmentally friendly. It was noted that the customer would need to be made aware of the type of vehicle that was collecting them at the time of booking. It was also noted that the vehicle would not be suitable as a Hackney Carriage vehicle.

Members voted on amending condition 1.5 to allow the single passenger "Fortwo" Smart Car and this was carried. 


\section{DECIDED: that}

Condition 1.5 be amended as follows:

1.5A The vehicle must have four wheels and a minimum of four doors. The doors must consist of two doors on near and offside of the vehicle and this does not include hatchback / boot doors.

1.5B A vehicle licensed to carry a single passenger must be of an approved model and specification and listed in the "Cheshire West and Chester Approved Private Hire Single Passenger Vehicle List."

\section{DESIGNATION, REMOVAL AND AMENDMENTS TO HACKNEY CARRIAGE RANKS IN CHESTER AND ELLESMERE PORT ZONES S63 LOCAL GOVERNMENT (MISCELLANEOUS PROVISIONS) ACT 1976}

This item was deferred to the next meeting.

43 CHANGES TO THE LAW AFFECTING SCRAP METAL DEALERS AND MOTOR SALVAGE OPERATORS

Members received a report giving details of The Scrap Metal Dealers Act 2013 which replaced the previous registration system for scrap metal dealers created by 1964 Scrap Metal Dealers Act, and motor salvage operators already licensed under the 2001 Vehicles Crime Act. In its place it created a new licensing regime. This scheme will be run and administered by local authorities and was based on the legislation for alcohol licences. Every scrap metal dealer / motor salvage operator will be required to have a licence, and operating without one would be a criminal offence. Under the new legislation the separate system for scrap metal dealers and motor salvage operators would end once the new Act came into effect.

Under the new regime, local authorities will be able to grant or refuse a licence where the applicant was judged not to be a suitable person to operate as a scrap metal dealer. The ability to regulate who was and who was not a scrap metal dealer was designed to improve the operating standards of those dealers who did not operate to the same standards as the majority of reputable dealers. The transition requiring dealers to hold a licence rather than merely registering with a local authority provided an opportunity to ensure that dealers who had been operating illegally were not able to do so.

The legislation comes into force from 1 October 2013, but with a transitional period lasting until 15 October 2013 for existing scrap metal dealers / motor salvage operators. This imposes a challenging timetable for local authorities in implementing the legislation. In order for anyone to carry on in business as a scrap metal dealer they will have to have a licence. A licence will last for three years and trading without a licence would be a criminal offence.

There were two types of licence specified in the Act; a Site Licence and a Collector's Licence. It was noted that a dealer can only hold one type of licence in any one local authority area.

\section{DECIDED: That}

the report be noted. 
Chairman

Date 